\title{
TEACHER PREPARATION REFORMS IN KOSOVO
}

\author{
Arberore Bicaj \\ arberore6@hotmail.com \\ University of Prishtina, Kosovo \\ Fatlume Berisha \\ fberisha@uwalumni.com \\ University of Prishtina, Kosovo
}

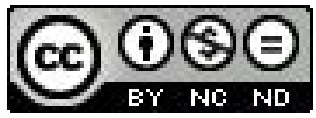

\begin{abstract}
Education is the key supporter of society, yet at the same time it is the main challenge to humanity and society. The need for change is incontestable in all fields, including that of education.

Education in Kosovo has taken a long, challenging and extremely difficult journey. Such challenging situations are a result of the low level of economic and social development in Kosovo. Today, education in Kosovo is considered to have made significant progress as a result of fundamental reforms of the education system towards standardization to the European Union education system.

This paper aims to analyze the historical, political and economic influence on the education system in Kosovo in general and the teacher education in particular, on its course towards implementation of the objectives of the Bologna Process and integration into the European Higher Education Area (EHEA).
\end{abstract}

Key words: Education, teacher, teacher qualifications, Bologna Process

\section{INTRODUCTION}

Education is considered a key component for the development of the society while at the same time it is equally a challenging process for humanity in general. According to Fullan, the need for change in any field, including the field of education, is imposed in every step we make (Fullan 1999, p.1). The need for changes found the education system in Kosovo (as a country in transition) in need of radical reform to enable it to reach accepted international standards.

In the past 50 years, Kosovo has gone through immense challenges mainly due to political developments and the resulting low level of economic and social development, and high poverty rate. Parallel to so many difficulties faced over time, we must not forget to mention the recent developments in the political context, directly affecting the field of education (Rexhaj 2011, p.6).

A proper education system is the basis for the development of every country. Under-developed countries, especially the countries in transition from socialism to democracy need substantial investment in the field of education (VanBalkon and Mijatoviq 2006, p. ix). In this context, the initiative for the implementation of the Bologna process in the education system in Kosovo was unquestionable. In Kosovo, 
particularly in the public University of Prishtina (UP), the implementation of the Bologna process started in the academic year 2001/02 (Bicaj 2011, p.29-35).

Among other things worth mentioning is the investments and reforms in the area of professional development for teachers. Modern education would not be successful without building teacher capacity that is the key factors for successful teaching and learning. Despite the low economic development and the constant lack of funds, the Kosovo government has made education its priority, including teacher education and training. The in-service teacher training in Kosovo was also supported in the critical years 2001 - 2006 by the Kosovo Educator Development Program (KEDP), financed by the Canadian International Development Agency (CIDA) and implemented by Universal Management Group and the University of Calgary (VanBalkon and Mijatoviq 2006, p.ix).

If we look back on the journey of the education system over the years in Kosovo, we will notice significant achievements coming primarily as a result of the importance population accord to education and the commitment of its teachers. Furthermore, the University of Prishtina (UP), the only public university in Kosovo until 2011, managed to survive the multitude of challenges and to implement most of the Bologna Process objectives and principles. Despite only 42 years in existence, the University of Prishtina can pride itself of having had a crucial positive impact in its society and of being on a promising course for a better academic future. Constant efforts are made at the UP to move towards parameters and standards of countries with advanced educational systems.

For political reasons (Kosovo has not signed the Cultural Convention of the Council of Europe) Kosovo is not formally part of the Bologna Process. Even though it benefits by participating in numerous initiatives of this process, Kosovo is still not part of the stock-taking action of the Bologna Process, and as a result, to date there are no specific analyses regarding the standardization of the education system in Kosovo with that of the European countries, or the level of application of Bologna objectives and dimensions in the Kosovo higher education in general and teacher education, in particular. This paper aims to give a modest contribution in this regard by describing and discussing the development of teacher education programs in Kosovo since the establishment of the University of Prishtina (in 1970) up to the current reforms according to the Bologna Process. Therefore, we will focus on the measures for standardization of the system and processes for education, training and qualification of teachers towards meeting the objectives of the Bologna Process.

\section{RESEARCH METHODS}

The main research method used in this paper is the theoretical analysis of available literature. The literature on teacher preparation, the existing data and the current status of the problem, were theoretically analyzed. Scientific findings in the field of education reforms, pedagogical documentations available from the Ministry of Education, Science and Technology (MEST), the current education system, and the teacher training programs in Kosovo as well as their political, economical and social influence in respect of teacher development programs were analyzed in order to draw qualitative conclusions and recommendations. 


\section{HISTORY OF EDUCATION IN KOSOVO}

The history of education in Kosovo dates back to seventeenth Century and it has been affected by various cultural and political influences (Koliqi 2004, p.19-25). The first Albanian school, a Catholic school, was opened in 1665. In 1910, the Ottoman Empire closed most of the Albanian schools operating up to that time (Pupovci 2000, p.31-82). In 1912 when Albania declared its independence, a majority of the Albanian population was found occupied by the Serbian Kingdom. Furthermore, the Serbian regime closed down schools operating in Kosovo at that time and serving the local population (Koliqi 2004, p.19-25).

During World War I, in 1916 in particular, education was organized in the Albanian language in Kosovo in the zones controlled by Austria-Hungary. At the end of World War I, Kosovo was again under the Yugoslav occupation. The rights of the Albanian population to be educated in their mother tongue were denied. During the World War II however, education in Albanian in Kosovo went through a phase of intense development when dozens of schools were opened in the larger settlements. In the post-war period (1945) Kosovo was re-occupied as a province of Serbia within the communist Yugoslavia. The former Yugoslav education system at that time was centralized, however in 1963 the system of education underwent decentralization and the competencies were devolved to the republics of the then Yugoslav federation. In 1969, finally the Kosovo Assembly adopted the Law on the Establishment of the University of Prishtina that has been in operation since $15^{\text {th }}$ February 1970 . This was one of the milestones in the history of education for Kosovo and the entire Albanian population (Universiteti i Prishtines, 2007). Furthermore, in 1974, the education system in Kosovo gained its legal autonomy still retaining links with as an integral part of the Yugoslav education system.

The year 1981 is well known as the year of the student and later popular demonstrations in Kosovo, which marked the beginning of two decades of attacks and detrimental developments for the system of education in Kosovo that finally resulted in 1999 in complete destruction of the system. Serbia treated the education system in Kosovo as the main source of political movement for Kosovo independence or as they referred to it 'irredentism and separatism'. Moreover, in 1989, Serbia destroyed the autonomy of Kosovo and its legal independence, whereas in 1990/91 legal measures against the Kosovar populations were imposed which brought about massive firing of Albanian teachers from schools and cutting all state funding to education for the Albanian population in Kosovo. This meant that the Kosovo education had to move on to a new phase by detaching itself from the Serbian system of education and creating an independent system of education (Koliqi 2004, p.19-25). Against all the odds, a parallel education system was set up that continued operating in private homes through popular support. As heroic as it was, this system operated under conditions that made any quality work impossible and, as a result, could have long-term consequences for the education of Kosovo youth in the decades to come.

The year 1998 was a tragic year for Kosovar population and the education system, when the Serbian army destroyed 60 school buildings and killed 68 teachers. During 1999 the political situation in Kosovo further deteriorated and the school 
year was interrupted leading to the closing down of schools. Right after the war of 1999, the recovery efforts to rebuild the education system took place, with a vital contribution from the United Nations (UN) and international organizations present at that time in Kosovo (Pupovci 2000, p.31-82). This phase of development of education in Kosovo marked a key turn towards educational reforms that would bring Kosovo back on the course of development. This was by no means an easy undertaking, which was reflected in immense obstacles partly influenced by the day-to-day politics present in Kosovo. Later, with the establishment of the Ministry of Education, Science and Technology (MASHT) in March 2002 a new education system came into being and the responsibilities to run the education were transferred to the local administration (Bicaj 2011, p.27).

Since then, Kosovo has generally undergone some serious transformations and fundamental reform processes in the education system. In 2001 the higher education in Kosovo formally adopted the Bologna Process in efforts to make the Kosovars also part of the European Higher Education Area (EHEA). As a result, the Kosovo higher education system went through a challenging period once again, mainly as a result of far reaching changes, misunderstandings, lack of ownership and resistance among the teaching and admin staff at the University of Prishtina.

\section{HISTORICAL DEVELOPMENT OF TEACHER EDUCATION PROGRAMS}

Pre-service teacher education in Kosovo is not very old. The first steps in teacher education (which are in fact the foundation of the national education system) were made by Ernest Koliqi, Albanian Minister of Education during the second World War. (Rexhaj 2011, p.16) Ernest Koliqi organized the teacher education for the first generation of Kosovar teachers in the normal school in Elbasan, Albania, in 1941-43 (Koliqi 2004, p.23).

In 1953 the first normal school (a kind of a teacher training college) was opened in Prishtina and that was the first institutionalized teacher-training program for the Kosovar population. High school students had to attend one additional year of pedagogical study and training to qualify as teachers. The normal school offered pedagogical theory and practical courses. Students of this school and the graduates from the Elbasan normal school were the main pillars of the Albanian education system for two to three decades after the World War II (Rexhaj 2011, p.16).

Meanwhile, there was a need for more schools and more teachers. In the late 50 's and early 60 's, a two-year teacher education post-secondary pedagogical school was established (in Prishtina - 1957, Prizren - 1962, Gjakova - 1967 and Gjilan -1972). The higher pedagogical schools (HPS - as they were called) trained teachers for preschool institutions, primary school teachers (0-4) and subject teachers (grades $5-8$ ), and are considered the core teacher education programs that would contribute also to building of capacity for the establishment of the University of Prishtina. Later (in 2002) under the University of Prishtina, these teacher preparation programs changed into offering three-year Bachelor studies. Until 2004, when these schools 
stopped taking new students, to leave way for new university teacher education programs under the UP, around 13,500 students had graduated in HPSs. It should be emphasized that these programs for teacher education in Kosovo were similar to the teacher education systems in the former Yugoslav republics. In addition to typical education programs in the Faculty of Education (established 2002) training teachers for ISCED levels 0, 1 and 2, future Kosovo teachers also graduate in other academic faculties of the UP. The Faculty of Philosophy, Faculty of Mathematics and Natural Sciences and the Faculty of Philology train teachers for general and vocational upper secondary schools. The drawback of the teacher preparation schools and faculties was that they provided more theory than practical experience, which later caused post-employment difficulties (Rexhaj 2011, p.17).

Moreover, in the year 1997, just at the time when the UP was functioning under difficult parallel conditions, due to the deficiency of teacher education programs, the Faculty of Pedagogy was established. Despite the most difficult circumstances, these faculties delivered four generations of teachers (Rexhaj 2011, p.20).

Then, in 2002 the Faculty of Education was founded, at first offering only preschool and primary education and then expanding with subject programs (Pupovci 2000, p.31-82). The Faculty of Education was established in cooperation between the Ministry of Education, Science and Technolofy (MEST), University of Prishtina and Kosovo Teacher Education Program funded by the Canadian International Development Agency (CIDA). The purpose of the faculty was to avoid fragmentation of the teacher education programs in Kosovo, meeting the four years of study criteria, the replacement of non-university teacher education degrees with university ones, and to offer in-service training. The faculty functioned in four centers, in Prishtina, Prizren, Gjilan and Gjakova, and was in line with the objectives of the Bologna Process, with the ECTS credit system, the duration of studies, competencies and learning outcomes.

For various reasons, in 2010 the Accreditation Agency of Kosovo (AAK) accredited the Faculty of Education for a limited time and not for all offered programs. As a result, the Faculty of Education had to undergo further reforms, to improve the quality of its programs. Upon AAK recommendations, the MEST has come up with a decision to restructure all teacher education programs operating in the University of Prishtina. Consequently, in 2011, the Faculty of Education is faced with a dilemma about how to move forward. Still it is not clear whether the faculty work toward fulfilling the requirements set by AAK and the Ministry decision, where the academic aspects of teacher education would be offered only by the relevant academic faculties, whereas the Faculty of Education would offer only professional-pedagogical programs, or continue functioning as it is only restructuring its programs and the staff. Moreover, it was verified that the Faculty of Education so far meets most of the professional, pedagogical and practical standards, as set by the MEST regulations - with a key setback being found in the quality of provision and structure and qualifications of its staff (Rexhaj 2011, p.23-25).

Furthermore, one of the new challenges facing Kosovo is the implementation of the new Kosovo Curriculum Framework (KCF), approved in 2011, and the building of new teacher profile needed for its implementation. The KCF provides for preschool, primary, lower secondary and higher education and aims to shift the teaching and 
learning to a competency-based approach. In addition, KCF aims towards the development and implementation of student-centered teaching and learning, inclusive teaching, flexibility, mobility, transparency and accountability. A critical change that poses significant challenges to the teacher education system in Kosovo is the introduction of integrated learning or integrated learning areas. As an illustration, natural science will be taught integrated as one subject - instead of the current tradition of physics, chemistry and biology (in some cases also geography) courses taught separately (MEST, 2011, p.23). As a result, the new KCF leads toward a need for the restructuring of educational programs, meaning necessary changes at the Faculty of Education. Changes in the pre-service teacher education for preschool and primary teachers (grades 0-5) are foreseen and also including the subject teacher education (for grades 6-9) In fact, in July 2012, MEST came up with a proposal to restructure teacher education at the UP, in order to adapt the curricula to the new KCF and other documents relevant for the pre-service teacher education and training. Among other things, the decision states that: "academic training for incoming teachers, will take place at the relevant faculties, while teaching and practical training take place at the Faculty of Education at all levels and educational profiles, including vocational education" (MEST 2012, p.2). In other words, the decision implies the need for significant structural and program changes in the sector of pre-service teacher education and training.

\section{THE NEED FOR PROFESSIONAL DEVELOPMENT OF TEACHERS}

The $20^{\text {th }}$ and early $21^{\text {st }}$ centuries saw implementation of programs for the professional development of teachers. The teachers during these stages are identified as being an influential factor in improving human potential and the formation of future generations. This implies the need for professional development of teachers, considering here also lifelong learning as a priority (VanBalkon and Mijatoviq 2006, p.19). Furthermore, one of the basic functions of teacher education is preparation of the teaching workforce, especially taking into consideration the changes that have occurred since the early 90s, in the Eastern European countries. To have critical teachers that formulate the teacher competences on knowledge- based society, and that in future will prepare capable future citizens, we need to develop teacher education even further (Pantic 2012).

As elsewhere in the world, efforts to reform the system of education in Kosovo date back to the beginnings of the education system in Kosovo. The purpose of the current reform is to move towards standardization of educational levels in Kosovo with those of the European Union, as follows: $5+4+3$, which coincides with primary education, lower secondary education, and upper secondary education. At the same time a reform of the higher education system is aimed at in accordance with the Bologna system and the reform trends in pre-university education (KCF)

Reforms according to the Bologna Declaration were not an easy task for the countries implementing it. It has raised the need for deep changes to the work functioning of teachers, and the changing roles of teachers have shown the need for changes in teacher education preparation (pre-service) to be more equipped for the 
future. Additionally, the need for the establishment of in-service teacher training, in accordance with Bologna Declaration has to take place (VanBalkon and Mijatoviq 2006, p.26-31).

\section{BOLOGNA PROCESS, IN RELATION TO THE PRE-SERVICE TEACHER EDUCATION}

The problem of adjusting teacher education adjustment to that of the Bologna Process has to do with the length of study and inclusive involvement of teachers in the context of social and cultural diversity. Duration of pre-service teacher education studies varies from country to country. For primary teachers, it varies from three years in Austria, Belgium, Iceland, Ireland and Spain, up to five years or more in Finland, France and Germany. Education for lower secondary school teachers varies from four years in Belgium and Iceland, to six or more years in Italy and in Spain. For teachers of upper secondary education (high schools) it lasts three years in Belgium, up to six years or more in Germany and Italy. Observed trends to provide teaching studies have been extended in almost all countries (OECD, 2003).

The Bologna Process, aims to establish a scheme based on two cycles, that of the university cycle and the postgraduate studies cycle. To gain access to the second cycle of studies needs successful completion of the first cycle studies, lasting a minimum of three years. The Degree obtained in the first cycle should be a relevant qualification for the labor market. The second Bologna cycle, will lead to a master's degree or doctorate. This, in a way, was seen as a good opportunity to end the extended period of study for becoming a teacher, giving the opportunity to all students who complete three years of studies to have access to the labor market (Fredriksson, 2005). According to the research made by Zgaga, most of the institutions adapting the Bologna Process, apply the two-cycle study systems (Zgaga 2002, p.33).

According to a study conducted in Kosovo during the year 2010/2011, with regard to the implementation of the study cycles for the offering of teacher training programs, it appears that almost all faculties applied the two-cycle studies. The Faculty of Education offers 4 years of bachelor studies followed up by master studies. The participants in the interview of the study say that: "the Bologna needs at least 3 years of study. Higher education in Europe by the year 1999 has been a real diversity and has been 1 year and 2 year programs higher education and the Bologna says that what is called higher education in Europe is that with minimum of 3 years of study. As far as the actual duration it is flexible and depends on the field. In some areas, the three-year studies are sufficient, while the faculties for teacher preparation, three-year study is not sufficient, and need additional studies for a period of 4 years. On the contrary, it should decrease the participation in teaching skills, or it will be harming the academic disciplines" (Bicaj 2011, p.87). Currently in Kosovo, the programs for teacher education offered at the institutional levels last 4 years. 


\section{THE CURRENT SITUATION FOR CONTINOUS PROFESSIONAL DEVELOPMENT OF TEACHERS IN KOSOVO}

Professional development is offered in all European countries and remains an important factor in meeting the challenges of the time and the different needs of teachers. Often, professional development provided does not lead to the achievement of higher qualifications, but is only aimed at improving existing practice, and that has to do with the so-called in-service training. On the other hand, professional development that leads to a new qualification is held in teacher preparation institutions usually as part of studies. Professional development is not mandatory in all countries. In the some EU countries, teachers are required to be part of ongoing training. In other countries, professional training is not mandatory, and in yet other countries is mandatory only when teachers want to upgrade their qualifications (VanBalkon and Mijatoviq 2006, p. 26-31).

Training and development of in-service teachers, has to do with education and training activities, which are undertaken in teaching in the schools directly aiming to improve their professional knowledge, skills and attitudes toward education of the children in the context of social and cultural diversity (Spasovski, et al. 2010, p.24).

Regarding the field of training and professional qualifications of teachers in Kosovo, it should be re-emphasized that Kosovo has undergone a number of changes in economic, political, cultural and social aspects, precisely because of the economic stagnations, the breakdown of the former Yugoslavia and the transition from the communist/socialist system into a democratic system. All these factors have had an impact on education. Furthermore, teacher training has also had its difficulties, undergoing major changes as a result of which today there is diversity in the field of teacher training. Teachers working in schools in Kosovo currently have graduated from normal schools, higher education pedagogy programs, Faculty of Pedagogy, teacher preparation from academic faculties, or other teacher preparation programs (technical, medical, legal, etc.). All of these programs, in addition to the higher education pedagogy, which was too short, rely only on teachers' academic preparation, leaving aside the professional and practical aspects. This issue led to the need for the establishment of the Faculty of Education, which provides for pre-service teacher qualifications (Rexhaj 2011, p.7-8). As a result of the diverse qualifications of teachers in Kosovo the need for professional development has increased. New qualifications and/or advancements of existing qualifications are offered and supported at the Faculty of Education

Up till now, the Faculty of Education has not provided any in-service professional training program. Such programs, in the form of training have been provided by non-governmental organizations, such as the Kosovo Education Center (KEC), Canadian Teacher Development Project in Kosovo (KEDP), German Development Cooperation Agency (Gesellschaft für Internationale Zusammenarbeit, GIZ), the European Agency for Reconstruction (EAR), project Finnish Special Education (Finnish Support to the Development of Education in Kosovo, FSDEK) and others. 


\section{PROFESSIONAL TEACHER DEVELOPMENT PROGRAMS IN KOSOVO}

One of the main challenges of the Faculty of Education was the qualification of current teachers. The Canadian program - KEDP and MEST in 2006 began preparations for implementation of the Programs for Teaching Professional Development while still working. The aim of the programs was to standardize the existing qualifications and training, and to establish teacher training in accordance with the legal provisions of the country and with the trends of the European standards. In that same year (2006) MEST, UP and a Canadian program (KEDP) signed an agreement for the functioning of the above mentioned program in the four centers of the Faculty of Education. The program was designed for the advancement and qualification of teachers with the background education from normal schools and higher education pedagogy to a fourth year the Bachelor program and had the full support of the Faculty of Education. The program was operating under the decisions of the governing council and the internal regulation agreed by the Statute of the University of Prishtina and MEST guidelines, and was one of the first programs functioning the life-long learning of teachers in Kosovo. To date, the program for teacher professional development while working continues to operate yet operates under a new name as Teacher Qualification Improvement Program (Rexhaj 2011, p.27-53).

It needs pointing out that the Teacher Qualification Improvement Program does not offer in service training for professional practices, yet offers qualification that lead toward professional advancement degree. Therefore, the Faculty of Education needs to work in the direction of building an in service training to provide for continuous professional development of the teachers.

\section{CONCLUSIONS}

Despite the difficulties that Kosovo has gone through over the years, such as the low social economic development, high levels of poverty and the political developments that have had a direct impact in the field of education, positive achievements with respect to education development in line with trends and standards in international education systems is clearly seen in Kosovo.

Furthermore, the professional development of teachers has an ethical role in their teacher practices and personal development. In addition, the Bologna Process has an important role in the equalizing and/or standardizing of teacher preparation with European standards. Till now the Faculty of Education is in alignment with the teacher professional standards and pedagogical practices set by the MEST, and at the same time the UP in collaboration with MEST is working constantly toward meeting the Bologna objectives.

The current teacher qualification improvement programs offered in Kosovo aim to enhance the teacher training toward achieving the bachelors of science of four years for all teachers with the past experiences (non-university training) of two years of study, in accordance with the Faculty of Education cycles of study, $4+1$. Therefore, the reforms toward teacher preparation in Kosovo in alignment with the European standards have taken a positive approach to date. 


\section{RECOMMENDATIONS}

- The Faculty of Education should change the teaching programs in accordance with the KCF and if necessary restructure the teaching programs.

- To build an in-service teacher training program at an intuitional level offered at the Faculty of Education.

- To continue reforms towards achieving the parameters and standards set by countries with the advanced system of education.

- To advance the education and teacher training towards development and implementation of student-centered teaching and learning, inclusive teaching, flexibility, mobility, transparency and accountability.

- To support the qualification of all the teachers in Kosovo to a four year Bachelor program in alignment with the Bologna Process.

\section{REFERENCES}

Bicaj, Arberore. 2011. Procesi i Bolonjes dhe kurrikulat ne fakultetet e mesimdhenies ne Universitetin e Prishtines [Bologna process and curricula in teaching colleges at the University of Prishtina]. Prishtine : Libri shkollor.

Fredriksson, Ulf. 2005. The Bologna Process and its implemetnation for education system in Europe. Sweden : Wingspam-Pedomerphosis communique, Vol. 1, p. 26-35.

Fullan, Micheal. 1999. Forcat e ndryshimit [Forces of Change]. London : Taylor and Francis.

Koliqi, Hajrullah. 2004. Sistemi i arsimit ne Kosove [The education system in Kosova]. Prishtine : Libri shkollor.

MEST. 2011. Curriculum Framework for pre-University Education of the Republic of Kosovo. Prishtine : Ministry of Education, Science and Technology.

MEST. 2012. Sipas vendimit nr. 191/01B (According to decision nr. 191/01B). Prishtine : Ministry of Education, Science and Technology.

OECD. 2003. Education at Clance. Paris : Organization for Economic Cooperation and Development.

Pantic, Natasa. 2012. Teacher education reforms between higher education and general education transformations in South-Eastern Europe: Reviewing the evidence and scoping the issues. CEPS Journal, Vol. 2, p. 71-90.

Pupovci, Dukagin. 2000. Shifra dhe fakte mbi arsimin e Kosoves [Figures and facts about Kosovo education]. Prishtine : Kosovo Education Center.

Rexhaj, Xhavit. 2011. Kualifikimi i mesimdhenesve te Kosoves pa shkeputje nga puna dhe standardet perkatese evropiane [Qualifying Kosovo teachers job and the relevant European standards]. Prishtine: Punim ne doreshkrim.

Spasovski, Ognen, Ballazhi, Safet and Friedman, Eben. 2010. Mapping policies and practicies for the preparation of teachers for inclusive education in context of social and cultural diversity: country report for the Former Yuggoslav s.l. Bologna: European Training Foundation.

Universiteti i Prishtines. 2007. Pasqyra e planeve mesimore dhe e personelit akademik per vitin 2007/2008 [Review of lesson plans and academic staff for the year 2007/2008]. Prishtine : kyreredaktor Destan Halimi, Universiteti i Prishtines.

VanBalkon, Duffie, \& Mijatoviq, Snezhana. 2006. Aftesimi profesional - Pervoja nga mesimdhenesit per mesimdhenes [Professional training - Expereinces of teaching teachers]. Kalgari : Education Development Program.

Zgaga, Pavel. 2002. Teacher Education and the Bologna Process: A Survey on Trends in Learning Structures at institutions of teachers'education. Kranjska Gora, Slovenia: Conference Paper. Erasmus Intensive Programme, EPAC - Education Policy Analysis in a Comparative Perspective. 